ARTICLE

\title{
From Monopoly to Monopsony Capitalism
}

\author{
Dev Nathan ${ }^{1,2,3}$
}

Accepted: 18 October 2021 / Published online: 10 November 2021

(c) The Author(s), under exclusive licence to Indian Society of Labour Economics 2021

\begin{abstract}
This paper argues for the characterization of contemporary capitalism as monopsony capitalism and, specifically, as global monopsony capitalism. This means that the degrees of buyer power should be added to the usual demand-supply analysis of markets for labour power and other inputs. Monopsony is used to understand the nature of global value chains, within which the paper distinguishes high, medium and low levels of monopsony power and outlines the main features of labour conditions in these different levels of monopsony power. The paper also sees how the working of monopsony power is gendered. The concluding section points to the difficult task of forming countervailing power in the age of global monopsony capitalism.
\end{abstract}

Keywords Monopsony $\cdot$ Power in markets $\cdot$ Globalization

JEL Classifications F66 · Impact of globalization · Labour · J42 · Monopsony

\section{Introduction}

In March 2020, as the COVID-19-pandemic-induced recession struck many parts of the world, garment brands from the Global North took action to protect their cash reserves and share values. Garment suppliers in Asia ended up with the largest number of cancelled orders. Many brands went beyond that and refused payment for supplies already delivered to them, supplies that had been completed and were in the process of being shipped, and contracted supplies for which suppliers had purchased fabric and other inputs (Anner 2020; AEPC 2020; AFWA 2021). These actions were

Dev Nathan

nathandev@hotmail.com

1 Institute for Human Development, New Delhi, India

2 GenDev Centre for Research and Innovation, Gurgaon, India

3 Centurion University of Technology and Management, R. Sitapur, India 
taken even as governments in the Global North began pouring in money to shore up their firms and stock markets and to support their workers.

In India and other garment-supplying countries of Asia, such as Bangladesh, Cambodia, Indonesia and Pakistan, when the cash flow stopped, suppliers closed factories and laid off workers. Most workers were not paid, even for work they had already done. Workers who were indirectly employed through labour contractors found that some contractors even switched off their phones and disappeared. As detailed in the AFWA report Money Heist, there was a massive wage theft-one that pushed more than $80 \%$ of garment workers in six countries (Bangladesh, Cambodia, India, Indonesia, Pakistan and Sri Lanka) into poverty (AFWA 2021). Over the next few months, brands revived their demands and contracted new production. Suppliers re-opened factories and workers came back.

This dramatic episode, a twenty-first-century tragedy, demonstrated the power of the garment brands. Not only could they push the burden of the recession on suppliers and their workers, but they could do so confident in the knowledge that suppliers and workers would return when required. The economic power of brands visà-vis suppliers and garment workers is monopsony, or, more correctly, oligopsony, where the input market is dominated by buyers who exhibit power in the markets for inputs. Although the term monopsony is almost a hundred years old, going back to Joan Robinson in her book Imperfect Competition (Robinson 1987/1969), it is not much used in economic analysis, in which attention is paid to monopolies in the product market. However, the wage theft of 2020 brutally showed the importance of paying attention to the power of oligopsonist brands in global markets for manufactured garments and, consequently, for labour in their production.

However, through their association, Bangladeshi garment manufacturers had provided the initial data for the exposure of contract-breaking by the brands (Anner 2020) and were able to threaten brands that they would not be allowed to give future contracts in Bangladesh if they did not pay for contracts completed when the recession struck. This was something that an individual Indian supplier was unable to do. ${ }^{1}$ The supplier had to accept the loss and return to the brand. This is a clear example of how suppliers can be tied to brands and are inelastic in their supply responses. Therefore, the suppliers cannot act against contract violations by brands.

Workers were also cheated of due wages. However, when offers of employment revived, even though the wage offered was far less than what they had received earlier, they had no option but to go back to work at the lower wage, demonstrating the inelastic supply of labour.

Apart from characterizing these markets as involving various degrees of monopsonistic power, this paper argues for the characterization of contemporary capitalism as monopsony capitalism. This is different from the twentieth-century characterizations, first by Lenin (1966/1917), and then by Baran and Sweezy (1966), of capitalism as being monopoly capitalism. Over the last half-century, monopoly capitalism has transformed into global monopsony capitalism, in which low- and middle-income countries of the Global South remain subjugated to the high-income

1 This was revealed to the author by a medium-scale Indian supplier. 
countries of the Global North. Some economies that were part of the low- and middle-income countries, most notably South Korea and China, have themselves moved from being suppliers in global monopsony capitalism to becoming headquarters of global monopsony capitalism. However, the overall structure of the global economy is one of monopsony capitalism.

The primary objective of this paper is to argue for the characterization of contemporary capitalism as monopsony capitalism and, specifically, as global monopsony capitalism. The secondary objective of this paper is to argue for an explicit introduction of degrees of buyer power (monopsony power) as an addition to the usual supply-demand analysis of markets for labour power and other inputs, as argued by Alan Manning (2003). Monopsony power allows employers to push wages below what would be market-determined levels, just as monopoly power allows producers to push up prices.

After defining monopsony and its relation to monopoly, we look at the importance of studying monopsony, both as a feature of global economic relations and as a pervasive characteristic of labour markets in the monopoly economies of the Global North and global economic relations. Then, there is an account of the manner in which global monopsony capitalism arose from the 1970s onwards through global labour arbitrage. The formation of islands or zones of monopsony ${ }^{2}$ within the larger labour force is then discussed. We should note that monopsony power is not uniform across all types of production. The factors that distinguish high, medium and low monopsony power with input suppliers and labour are discussed, followed by a summary of labour conditions in conditions of high, medium and low monopsony power in GVCs. Next, we consider how the working of monopsonies is gendered. The conclusion draws together some policy lessons, both for labour and development.

The paper makes a number of contributions to discussions of global production and labour. It characterizes contemporary capitalism as monopsony capitalism, as against the earlier characterization of monopoly capitalism. It shows how monopsony operates with regard to input producers, including small producers and capitalism firms, and also workers. It discusses the role of technological changes and the formation of a global labour force in the creation of global monopsony capitalism. It identifies degrees of monopsony power, their bases and investigates some of the dynamics of change in monopsony power.

A limitation of this paper is that it is an initial exploration illustrating the relevance of the concept of monopsony in understanding contemporary capitalism. This paper will have to be followed by deep and systematic empirical investigations into the working of monopsony capitalism.

2 The phrase 'zones of monopsony' was used by Gerry Rodgers in an email. 


\section{Defining Monopsony}

Monopsony is a market relation in the buyers' market, or the market for inputs, where there are one or a few buyers who have significant power in these market for inputs, chiefly labour. The term monopsony was coined at the request of Joan Robinson (Thornton 2004). Instead of a market with a few sellers, she wanted a term to describe a market with few buyers (1933/1969) as the converse of monopoly.

The term monopsony, however, has not really caught on in economic analysis and remains a curiosum (Manning 2003). There has been some contemporary analysis of monopsony, particularly in labour markets in current highincome countries (HICs). In these cases, the situation is not just one of one or a few buyers of labour power, but of an inelastic supply of labour, which means that because of various frictions in the labour market, buyers are able to exercise power in setting wages (Manning 2003). Thus, while studying the labour market, it is necessary to introduce power relations into the analysis, in addition to the usual demand and supply relations.

We can take monopsony to be the application of power in the buyers' market; in a manner analogous to the monopolist who uses power to set prices in the sellers' market. Monopsony is manifested in the market for inputs, whether goods or services, and the market for labour, which is also an input into production. If product monopolies are mainly based on the monopolization of knowledge, as argued in Durand and Milberg (2019), Kaplinsky (2019), Nathan (2020) and Nathan et al (2022a), then we have two-faced or Janus-faced knowledge monopolies. As pointed out by Joan Robinson, "The monopolist must necessarily be a monopsonist in the factors he employs" (1987/1969, 3).

To summarize the condition of two-faced knowledge monopolies: When facing consumers they are monopolies, using their monopoly power to set prices in the product market; when facing suppliers and labour they are monopsonies, using their monopsony power to set the prices of input suppliers and wages of labour. In the case of the product, the ability to set prices depends on the inelasticity of demand; in the case of input markets, the ability to set prices depends on the inelasticity of supply. The monopolization of knowledge interacts with the inelasticity of demand to create monopoly product pricing; the same monopolization of knowledge interacts with the inelasticity of supply of inputs (including labour) to create monopsony pricing in input markets. Consequently, we have three variables: the monopolization of knowledge, the inelasticity of demand for products and the inelasticity of supply of inputs (including labour), to create pricing and related outcomes in product and input markets.

In this paper, the discussion of monopsony is extended beyond capital-labour relations to examine relations with both small producers and even capitalist input suppliers. The contracted supplier relationship with brands exists in global production networks (GPNs), also called global value chains (GVCs).

Another type of monopsony is that of trading relations between myriad smallholder producers with traders. Even at the local level, there are inter-linked 
markets, where debt is given on condition of tied supply at lower-than-market prices at the time of harvest. The debt relation gives the buyers' power in the product markets. In many cases, the traders may be large corporations working through their agents.

The third type of monopsony dealt with is that of the employer who is able to deploy power in relation to the worker. The worker is taken be one who may be free in Marx's sense of being free of the means of production; but the notion of the worker can also be extended to that of the gig worker who owns the means of production, such as the hotel service provider who owns the hotel room, the taxi driver who owns the taxi or the delivery worker who owns the motorcycle or bicycle. In the first case, the so-called free worker needs to seek an employer in order to gain access to the means of production. In the second case, the gig worker needs the platform in order to access customers. By owning the means of production, the gig worker is similar to the smallholder agricultural producer, but the gig worker is different in not selling services directly on the market, but via the platform.

In each of these cases, there is substantial buyer power-a power that is identified as monopsonistic power of buyers, based on control of access to markets. What in platform economics is described as control of the customer interface (Goodwin 2015 ) is really control of access to the market. What this paper aims to show is that this buyer power has to be brought into the analysis of supply-demand interaction in the market. As Manning points out (2003), this does not substitute for demand-supply analysis, but adds the element of power into this analysis.

To summarize the use of terms in this paper: monopsony capitalism is used to characterize capitalism with the dominant feature of the power of employers and brand-lead firms in markets for labour and other inputs; monopsony is the policy used by firms to create such power in the market; oligopsony is the usual condition where there is more than one (but only a few) monopsonists in the market for labour and other inputs; and oligopsony policy is also the policy of these buyers and employers, particularly when there are collusive actions in the market.

\section{The Pervasiveness of Monopsony}

Monopsony in markets (such as agro-foods) for labour and other inputs is not just a feature of specific markets, but a more general phenomenon of the nature of contemporary capitalism, which can be identified as monopsony capitalism. Furthermore, this is also global monopsony capitalism in that it involves cross-country monopsonist relations between headquarter firms (largely in the Global North) as contract buyers, with manufacturers and labour in the Global South.

The identification of monopsony capitalism or global monopsony capitalism as the form of present-day capitalism was earlier made by Ashok Kumar (2020), Dev Nathan (2020) and in Nathan et al. (2022a). In Nathan (2020), the more accurate term oligopsony was used as the situation is that of a few buyers in the market. This is particularly important where there is collusion between oligopsonist firms-for instance, in tacit agreements not to poach workers from each other's enterprises. At the same time, monopsony should always be understood as involving degrees of 
monopsony (Manning 2003), just as we accept that monopoly involves degrees of monopoly.

Global value chains (GCVs) and the platform firms are both forms of monopsony capitalism, as will be argued later. With global value chains accounting for at least $70 \%$ of global trade (OECD 2020) and platform-based hyper enterprises (Amazon, Alphabet, Facebook, Tencent and Alibaba) accounting for 5 of the top 10 corporations by market capitalization, the world can truly be said to be in the age of monopsony capitalism. However, monopsony capitalism is not always global, as domestic variants also arise due to the value chain form of organizing production spreading across all markets.

The influence of GVCs as monopsony capitalism extends beyond GVCs. As supplier countries compete in reducing costs to secure market access, they have undertaken competitive devaluations, which impoverish and affect the whole economy. ${ }^{3}$

Much of the trade in agricultural raw materials is also of the monopsony variety, with few buyers and many small sellers. For instance, three corporations (BayerMonsanto, Dupont-Dow and Chem China-Syngenta) account for $60 \%$ of global trade in commercial seeds, while four corporations account for $60 \%$ of global trade in wheat, soya and corn (Oxfam 2018,4). Where there were collectives of small producers, such as the International Coffee Alliance (ICA), which was able to raise and stabilize coffee prices, it was dismantled and "roaster-driven" monopsony power was established (Grabs and Ponte 2019). In raw cotton, the USA and EU systems of support to farmers keep raw cotton prices low. This helps reduce production costs, benefiting brands who captured the bulk of value super-profits, while it impoverishes farmers in West Africa (Nathan et al. 2022a).

Discussion in this paper is mainly about global monopsony in supplier and labour markets in the Global South, but recent studies show that monopsony or employers' power is a problem and quite pervasive in countries of the Global North too. A recent review of studies of monopsony in the labour market in the Global North by Manning (2020) pointed out that there is a revival of interest in monopsony, which he attributed to "anxiety about the rise in inequality" (20). The review also concluded "That labour markets have important elements of monopsony power is becoming clear beyond reasonable doubt" (22). Another review of similar labour market studies pointed out that they "represent a considerable cross section of employers, which suggests that the allocative problems with monopolistic exploitation are far from trivial" (Ashenfelter et al. 2010, 209). A recent study of monopsony power in India and China found that the labour share was marked down by about 10 percentage points in China and 15 percentage points in India and that there was evidence of collusive behaviour of employers in China (Brooks et al. 2019).

A study of 634 establishments in the USA showed that employees in $49.4 \%$ of firms and $31.8 \%$ of all employees had to sign "noncompete agreements" that banned workers from going to work for a rival or starting a company for a period of time after leaving a job (Colvin and Shierholz 2019). This was common, not only in those in jobs with high education requirements, but also in low education and pay units

3 Thanks to Raphie Kaplinsky for drawing attention to this beyond GVC influence. 
such as in construction and fast food. There was the revelation that Apple, Google, Intel, Adobe, Intuit and Pixar had carried out a coordinated effort to push down their workers' wages (Konczal 2014). Of course, those who contributed to build intellectual property in these corporations did not get any rights to what they helped create (Pistor 2021, 13). Calvin and Shierholz estimate that $27.8 \%$ to $46.5 \%$ of the American work force is subject to such noncompete agreements. Another study of the US labour market concluded that labour market concentration with a few firms dominating the market has led to a reduction of advertised wages by 17\% (Azar et al. 2019). Monopsony and the "Amazon effect" are said to have figured prominently in the 2018 US economists' Jackson Hole Economic Policy Symposium (Sasi 2018). The importance of monopsony has been recognized in the US President's Order on Promoting Competition. The first point in this is to "make it easier to change jobs and help raise wages by banning or limiting noncompete agreements" (The White House 2021).

Monopsony power is also manifest in the new platform-based firms. ${ }^{4}$ Platforms operate on both sides of markets. They appear both as buyers and as sellers. Due to this, they are conjoined monopolies and monopsonies. They are monopolies in selling goods and services. They are also monopsonies in buying services that they sell.

The e-commerce platforms (Amazon, Alibaba and Reliance) have taken outsourcing to what seems to be the ultimate level. Initially, Amazon directly bought and resold products, starting with books. Alibaba came into the field and created a new form of outsourcing. It held no inventory and passed on all the costs and risks of holding inventory to the brands. Adopting this model, the e-commerce giants have become monopoly retailers with no or little inventory.

The platforms are increasing their monopsony power as buyers of products as they increase their monopoly role as sellers of products. With the growing importance of platforms to product producers, brands are becoming just part of a bouquet of products. Luxury apparel and accessory brands are going the way of wines. Quality wines are sold, not in separate shops, but in retail stores that offer a full range of wines at different price points. As a sign of the growing importance of platform sales, brands are being asked to package their products to suit e-commerce delivery systems. They are also forced to accept the deep discounts of flash sales. As the share of e-commerce grows, the monopsony power of e-commerce platforms will grow at the cost of brands.

New monopsonies have come up as service providers, such as those of taxi rental services. Uber (USA and many other countries), Didi Chuxing (China) and Ola (India) form oligopolies selling these services. In fact, they have virtually driven competitors such as traditional taxis and radio taxis out of business. They now account for almost all the taxi services available in their areas of operation. This gives them power in fixing prices in the product market, best manifested by their use of surge pricing in peak times. They are also monopsonies in buying the labour of various types of workers.

\footnotetext{
${ }^{4}$ The analysis of the economics of platforms is dealt with in more detail in Nathan, Kelkar and Mehta (2022b).
} 
The platform firms have created a new form of outsourcing, which is named crowdsourcing (Howe 2006). In the older outsourcing model, a headquarter company contacted one or a few potential suppliers to create value chains. In the crowdsourcing model of the platforms, a platform-mobilized crowd is used to carry out outsourcing.

The crowdsourced workers are the gig workers of the platforms. The gig workers carry out the services that the platforms sell to their customers, whether they are taxi rides by Uber, Ola and Didi Chuxing, hotel rooms by Airbnb, domestic and beautician services by the Indian firm Urban Company, and so on. In order to provide these services, they purchase the labour power of the workers referred to earlier, whatever be the legal status of these service providers. They pay them service performance or gig-based wages.

The platform-based firms have taken outsourcing to a new level. Instead of outsourcing specific tasks, they create the business and then outsource everything, keeping to themselves only the customer interface, or access to customers, which is what allows them to capture much of the value created through the platform economies. "This is a continuation and intensification of the longer process of outsourcing, minimizing the costs and risks to themselves" (Woodcock and Graham 2020, 44). As a result, Airbnb operates the largest hotel service in the world without owning a single room, while Uber owns no taxis. All the asset-ownership costs and associated risks are borne by the room and taxi providers.

Through this outsourcing, the platforms have created huge armies of workers. In the USA, Uber has 3 million drivers. In India, before the pandemic, Uber had 1.5 million workers; while Ola had 1.2 million workers. The two food delivery platforms in India each had around 0.5 million workers. In comparison, the Indian conglomerate, the Tatas, including its IT service company, TCS, had about three-quarters of a million workers. These platforms are truly oligopsonies, on a scale not seen before-two or three buyers dealing with millions of sellers of labour services.

Therefore, platforms have created a new form of monopsony capitalism, where the crowdsourced gig workers bring the means of production to the production process. In a way, this is similar to the petty capitalist production of the smallholder. However, it would be a mistake to see this as merely a new incarnation of an old phenomenon, as old wine in a new bottle. The analogy of smallholder production in agriculture holds to an extent. However, a deeper look is needed to understand the features of the evolving gig monopsony economy as a new form of capitalism. Of course, it will have resemblances with both smallholder production and wages as a labour-power transaction, but it is necessary to go beyond both of those analogies.

Monopsony exists not only in new forms of organization, such as in GVCs or platform economies, but also in traditionally organized labour and other input markets. In India, there is a discussion of power as force in matters of bonded labour and trafficking. In agricultural markets, there has been analysis of the nature of interlinked markets. However, inter-linked markets also mean that the trader-cum-moneylender can turn the small producer's debt-bondage into power as a local monopsonist buyer in the market for products. However, even an obvious case of monopsony, such as indigenous peoples isolated in tea plantations in West Bengal and Assam who are entirely dependent on plantation owners, has not been discussed as a case 
of monopsony power in the labour market. Gender-based, ethnic-, religious- or caste-based discrimination are all deviations from profit-maximizing behaviour in competitive markets. Are these labour market discriminations not manifestations of monopsony power in labour markets? Our understanding of labour market outcomes would be improved by introducing degrees of monopsony as power into demand and supply analysis of labour and other inputs.

Monopoly pricing power is used to capture consumer surplus. The monopolist is likely to carry out discriminatory pricing. In monopsony, the attempt is to capture surplus value created in production through pushing down prices of labour and other inputs. ${ }^{5}$ The monopsonist can also carry out discriminatory pricing, e.g. paying women less than men performing the same task.

The ability of monopsony to push down the prices of labour and other inputs has some important implications for the distribution of the value added. Monopsony analysis could constitute an element in the overall analysis of wage shares, not just with reference to the class-wise distribution of wage shares, but also the inter-country distribution of shares in global production, as is discussed in detail with regard to the global production of garments in Nathan et al. (2022a).

Monopsony looks like an appropriate concept for analysing distribution between classes and within countries in the global economy. It forces one to bring power relations into the analysis of supply and demand in market-based outcomes. The next section looks at the way in which global monopsony capitalism developed in the globalization of production in the form of contemporary global value chains (GVCs).

\section{GVCs and Labour Arbitrage}

How did global monopsony capitalism come into being? A monopsony in the input market is built on a monopoly in the product market. As Joan Robinson (1987) put it, "The most important cases of monopsony will occur in connection with monopoly. A monopolist must necessarily be a monopsonist of the factors which he employs" (1969: 227). The crucial factor in the creation of the monopoly-monopsony relation is that of the monopoly created or supported by intellectual property rights (IPR) protection such as the TRIPS regulation of the WTO. These monopolies are built on knowledge monopolies, whether of codified knowledge as patents, or tacit knowledge in copyrights and trademarks (Durand and Milberg 2019; Kaplinsky 2019; Nathan 2020 and Rikap 2020). This has also been termed intellectual monopoly capitalism (Pagano 2014 and Rikap 2021), emphasizing the role of intellectual property rights' protection in the creation of monopoly.

The change from monopoly to global monopsony lies in that instead of the vertically integrated economic production system of the $\mathrm{MNC}$, which combined design, manufacture, brand and market functions, the MNC headquarters began

\footnotetext{
5 I owe this and the next paragraph to the prompting of Gerry Rodgers, from whose email I have borrowed some of this conceptualization.
} 
to concentrate on just the pre-production tasks (design) and post-production tasks (branding and marketing), while outsourcing manufacturing. This concentration on core competence (Hamel and Prahalad 1990) was also a concentration on tasks where the MNCs had knowledge protected by intellectual property rights in the forms of patents, copyrights and trademarks. They could enable them to secure rents or excess profits. The commoditized forms of knowledge in production which could only secure competitive profits were outsourced. This outsourcing was not to buying from the market, but in contracted production. Furthermore, offshoring was based on labour arbitrage or the use of differences in wage rates between headquarter and supplier economies.

This was already happening in the garment industry (Anner et al. 2014) and the automobile industry (Helper 1991) in the USA, where designers-cum-retailers and the car designers-cum-assemblers were building monopsony relations with input suppliers. The real change that came about in the last decades of the twentieth century was the internationalization of this process using labour arbitrage. Several technological advances made this internationalization possible, along with institutional factors such as the growth of a specialized labour force with the requisite managerial and production capabilities. ${ }^{6}$

One technological advance that helped promote the splintering of production was the development of information and communication technologies (ICTs), which made it possible for the headquarter (or lead) firms to convey detailed specifications and even monitor complex manufacturing processes at a distance. The other technological advance was that of containerization in transport, which reduced the costs of transportation between different production centres.

However, for outsourcing to become global offshoring, two more conditions were necessary. The first was the development of manufacturing capabilities and of both managerial and work forces in supplier countries. ${ }^{7}$ With the spread of education and development policies that fostered industrialization (much of it through import-substituting industrialization) unevenly across different countries in Asia, the capability to carry out the manufacturing activities that lead firms sought to outsource was created.

For outsourcing to become offshoring, there needs to be a crucial difference in wages for the same tasks. This leads to labour arbitrage as the hallmark of GVC offshoring. It should be added that there is also an arbitrage in environmental services, as both the costs of services such as clean water and the usually neglected cleaning up of waste products are much lower in supplier economies, when compared to headquarter economies (Nathan et al. 2022a).

Offshoring to supplier countries of the Global South vastly increased the number of workers who could be drawn into GVC production of both goods and services.

\footnotetext{
${ }^{6}$ The role of information technology (IT) in the development of GVCs, calling it the unbundling of production, is discussed in Richard Baldwin (2016).

7 The terms "headquarter firms", "headquarter economies", "supplier firms" and "supplier economies" are borrowed from Baldwin (2016). GVC analysts tend to use the term "lead firms" for Baldwin's headquarter firms.
} 
While this process had started with the smaller East Asian and South-East Asian economies such as South Korea, Taiwan and Thailand, it really picked up steam with the opening up of China, the breakup of the Soviet Union and the opening up of India, all in the period between 1986 and 1991.

Richard Freeman (2005) pointed out that with the opening of these economies, the addition of 1.47 billion workers from these countries more than doubled the size of the world's connected labour force. Freeman estimated that since these new entrants brought little capital with them, the global capital/labour ratio was cut by 55 to $60 \%$ from what it would otherwise have been. This shifted the balance between capital and labour in favour of labour. Andrew Glyn correctly predicted that it would reverse the post-Second World War shift in the distribution of income in favour of labour (Glyn 2002, 2006). This would be due to the increase in, "Marx's reserve army of labour going global", as a result of which, "The bargaining chips would be in the hands of capital to a degree not seen since the industrial revolution" (Glyn 2006).

With the continental economies of China and India undergoing the Lewisian transition of workers from agriculture to industry and modern services, the result was hyper-competition among the supplier economies of the Global South. This hypercompetition for offshored employment was reflected in the various tax concessions and restrictions on workers' rights to form trade unions and to strike given in Export Processing Zones (EPZs). The formation of GVCs is the birth of global monopsony capitalism in manufacture and services.

One can distinguish two forms of value capture in GVCs. The first is that of the "normal" method of labour arbitrage. This GVC practice takes advantage of differential wages for the same tasks performed in different locations. For example, IT engineers in India have been paid a fraction of what their counterparts performing the same tasks in the Global North would get. This is the normal method of value capture, exemplified in Arghiri Emmanuel's Unequal Exchange (1972) and for analysis of contemporary labour arbitrage, in John Smith (2016), Dev Nathan (2018) and Intan Suwandi (2019).

The second method of value capture is through the purchase of inputs, whether of gendered labour, farmers' products, or environmental services, at prices below their costs of production, as discussed in Nathan et al. (2022a). Marx's prices of production are the sum of the various inputs that go into making a product, plus a normal profit. This is also a neo-Keynesian definition of cost. With regard to labour, the cost of production and reproduction of labour power can be taken to be the living wage. Comparing this with the actually existing wage, the Asia Floor Wage Alliance estimates that garment workers' wages are less than $25 \%$ of living wages in Bangladesh and Sri Lanka, 35\% in India and Cambodia, going up to above $40 \%$ in China and $54 \%$ in Malaysia (AFWA 2021).

However, it is necessary to make a distinction between sites of value extraction and of value capture, with monopsony introduced into the scenario. Low prices of labour power, agricultural inputs and environmental services all reduce the cost of production in supplier factories. Through the operations of power in global monopsony structures, brands capture the benefits of lower input prices. Value extraction from low-priced inputs may occur in the sites of production in the Global South, but 
that value is captured, through the dynamics of monopsony relations, by brands in the Global North.

Consequently, there is not only an accumulation of profits in the hands of brands, but also a transfer of surplus from the Global South to the Global North. This has been called a reverse subsidy in Nathan et al. (2022a). It is a reverse subsidy in a double sense. A subsidy extracted from the poorest sections of producers in the value chain that, in addition, is transferred from the Global South to the Global North. In this capture of surplus, IP-protected rights over monopolized knowledge are combined with monopsony in global markets for labour and other inputs. This provides a succinct characterization of global monopsony capitalism, where global monopsony is combined with the structures of monopoly.

How do the brand-lead firms create and deal with monopsonies? We first look at the creation of islands of monopsony of tied-in input suppliers and workers. This is followed by a characterization of degrees of monopsony.

\section{Forming Zones of Monopsony}

The base of monopsony power is that of the inelastic supply curve of suppliers in relation to price, based largely on the difficulty of switching to other equally remunerative value chains. While the monopoly position of brands allows them to secure higher value in the product market, their monopsony position vis-à-vis suppliers allows them to capture value within the GVC, making sure that suppliers, with their commoditized knowledge production, are confined to competitive profit rates, while the brands themselves acquire monopoly profit rates.

The creation of zones or islands of monopsony in a GVC is a two-step process. The first is the creation of a larger-than-required base of suppliers. The second step is the creation of a surplus workforce for the sector or segment of production. We look at both processes here.

The manner in which these value chains are organized by the large brands/retailers to foster competition among suppliers can be gauged by the fact that global garment giants, Zara, H\&M and M\&S, each had about 1,000 suppliers around the world. This would add up to a global workforce of around a million workers each, though they would not be working full time for just these brands. On a much smaller scale, up to the 1980s, US auto-makers would have 7 to 8 suppliers for each part (Helper 1991), helping them to utilize competition among these suppliers.

Recessions tend to foster a consolidation of suppliers. However, a reduction in the number of suppliers does not necessarily lead to a reduction of monopsony power. Instead, it might increase brand power. An ILO study takes $35 \%$ of a supplier's output going to one brand as an indicator of higher monopsony power (Vaughan-Whitehead and Caro 2017). A reduction in the monopsony position of brands only occurs when the suppliers develop IPR-protected components, such as is the case with subassemblies in the automotive industry.

This is a classic type of monopsony buyer relationship with competitive suppliers, well-captured by the term "captive governance" in GVCs (Gereffi, Humphrey and Sturgeon, 2005/2018). Such a captive relationship also exists in the case of 
agro-foods such as cocoa, coffee, or even the more recent exports of fresh vegetables and cut flowers. In these cases, production is carried out not by firms but by smallholder agriculturists.

Contract manufacturers and suppliers also create their own surplus workforces. They need the surplus to respond to the volatility of orders. Spikes require more workers who cannot be recruited off the street. Thus, workers with specific skills are created in larger numbers for these spikes in demand and laid off when demand falls. Such surplus workforces are a feature of clusters.

The new platform firms have created surplus workforces by initially offering higher rates for gig work and then reducing them. In India, for creating a surplus work force, the taxi platforms initially charged relatively small commissions of $8 \%$. As the customer and driver base both got established, the platform commissions were increased to $15 \%$ and then $25 \%$ (SEWA 2021). Similarly, for delivery workers, the rates were reduced from Rs. 60 per delivery about four to five years ago to Rs. 15 or even Rs. 12 per delivery now (Ghosh et al. 2021, 29). As they need to meet monthly repayment requirements on work assets, the gig drivers cannot just leave platform employment, even when rates fall. Having a larger workforce than that required by the current volume of business is a way of utilizing this surplus labour to keep driver earnings low while increasing platform earnings. "The evidence indicates that on some online labour platforms there is excess labour supply, which leads to greater competition among workers for tasks assignment and puts downward pressure on the price of the tasks to be performed" (ILO 2021, 4).

Collusion among oligopsonies is often a feature of their market behaviour. Current US discussions on non-competitive behaviour of corporations has focused on "noncompete agreements" through which employees sign away their rights to going to work for or starting a competitive business (Colvin and Shierholz 2019). The US President's Executive Order on Promoting Competition also focuses on noncompete agreements.

In India, the Times Group was reported to have signed "no poaching" agreements with the HT Group and the Telegraph (Exchange Media Staff, 2019). Indian IT service majors are also reported to have informal "no poaching" agreements. Such agreements reduce or even eliminate competition among oligopsonies, preventing salaries from rising to the levels that could be expected with competition.

Monopsony power, however, is not uniform across all kinds of GVCs, making it necessary to look at degrees of monopsony.

\section{Degrees of Monopsony}

What GVC analysis identifies as forms of governance (Gereffi et al. 2005/208), i.e. the manner in which headquarter or lead firms manage orders and related relations with suppliers, are sets of buying practices. We start with the assumptions that the intensity and frequency of sets of buying practices showing monopsony power in the GVC are related to: (1) the knowledge complexity of the tasks being carried out by the supplier and (2) the costs of switching. Knowledge complexity of supplier tasks relates to power in the GVC relationship between lead firms 
and suppliers. A supplier's cost of switching is reflected in the inelasticity of the supply curve. The difference with Manning's model is that while he assumes the independent decision-making power of the employer, in this model the GVC supplier is constrained, including in its actions vis-à-vis workers, due to its contractual relations with brands. The more complex the knowledge required of suppliers, the lesser the power of the lead firm, and vice versa.

Are these reasonable assumptions? In garments, where the knowledge required for production is not very complex and not protected by IP systems, brands calculate costs (including labour costs) based on national minimum wages. On the other hand, lump-sum contracts for IT services do not specify labour or other costs. In the case of patent-protected components such as sub-assemblies in the automotive chains, there would not be any labour costing in contracts for the supply of these components. These examples support the assumption that manufacturing complexity and their IP or reputational asset status would be inversely related to monopsony power.

The costs of switching are an indicator of suppliers' weakness in GVCs. Switching costs are important since the high costs of switching, relative to fixed investment and revenue, will influence the power dynamic in the monopsony relationship. The cost of switching relates to the opportunity cost or the difference with the income from the next-best alternative.

The higher the opportunity cost, the higher the cost of switching. The high cost of switching is what makes both garment manufacturers and agri-foods producers captive in their respective value chains. On the other hand, an electronics plant can switch from manufacturing one type of product to another. It can switch from assembling TVs to assembling PCs. It can also take up the manufacture of other electronic products, such as those related to health, automobiles and aerospace (Raj-Reichert 2018). This will give electronics assembly a degree of freedom in its relationship with buyers. An engineering factory can also switch its production.

IT service providers have the greatest ability to switch from one buyer to another, and even from one sector to another. IT is a general-purpose technology, which can be applied in literally every domain or sector of economic, social and political activity. This gives IT service suppliers the greatest ability to switch. An IT service firm can switch from supplying to the financial sector to the engineering one or even the chemicals sector. The major cost involved in switching would be that of acquiring the requisite domain knowledge.

To summarize this point, the costs of switching can be graded as high, medium or low in captive, modular and relational value chains, respectively. The cost of switching is directly related to monopsony power, with the high cost of switching related to high monopsony power and vice versa. Where low switching capability is combined with low knowledge complexity of the production process, we get a very inelastic supply system, leading to a high degree of monopsony power.

The inelasticity of supply, however, has to be related to both suppliers and their workers. This leads to the analysis of labour conditions in varying degrees of monopsony. 


\section{Labour Conditions in Varying Degrees of Monopsony}

That input-producing firms or farmers are caught in the monopsony relations could be understood in terms of their investment commitments, which is something they could not just liquidate. However, what about the workers of these input suppliers? Are they also similarly bound to remain within the industry or firm? This is something that needs to be analysed. It is, however, likely that while there is some mobility of workers between different manufacturers within the same industry, there is not much mobility of workers between industries or between value chains. Those who have acquired skills in the engineering sector are unlikely to be able to take their skill premium to the chemical or metallurgical industries. This would increase the opportunity cost of switching, making the supply of labour somewhat inelastic with regard to wages in the sector where they have worked. The reserve army of labour is then not a general reserve army, but one specific to a sector or segment of work. As pointed out earlier, this skillspecific reserve army is created by oligopsonies.

What are the features of employment conditions under monopsony? Some types of restrictive labour practices are clear candidates as manifestations of buyer power in the transaction. There is force involved in forms of forced labour. In some cases of child labour or bonded labour, there is debt or some other form of bondage. The extent of forced labour could then be used as an indicator, though not the only one, of the extent of monopsony power in a sector or a value chain.

In this section, we summarize the well-known findings of employment conditions in some key value chains about wages, employment security and forced labour, showing how they manifest different levels of monopsony power. This analysis uses 18 studies of garments, tourism, agro-foods, leather and other labour-intensive products, mobile phone manufacturing, telecom services, call centres and IT services in Bangladesh, China, India, Indonesia and Sri Lanka in the edited volume Labour in Global Value Chains in Asia (Nathan et al., 2016) and the more recent study of garment value chains in India, along with Bangladesh and Cambodia (Nathan et al. 2022a). Other studies are brought in as referred to in the text. From these case studies, I have summarized material on the conditions of workers in GVCs, classified by different degrees of monopsony power.

\section{High Monopsony Power}

How does monopsony work in garment value chains? What is key is the creation of a large workforce that can keep wages down. As we saw, major brands have up to 1,000 suppliers with about a million workers.

Many of the purchasing practices of brands had consequences for workers. Suppliers who are "bullied by brands" (Vaughan-Whitehead and Caro 2017, 21) to sell below costs pay $11 \%$ lower wages. Wages were $20 \%$ higher for buyers with diversified portfolios of brands compared to single buyers. A brand's dominant 
position is associated with a $23 \%$ increase in the number of temporary workers. Imposing prices below costs of production also results in a $20 \%$ increase in the number of temporary workers. The authors conclude that their study "highlights the fact that the relationship between brands and their suppliers helps to explain wages and working conditions at the end of the supply chains in terms of the high number of working hours, stressful work rhythms and also low wages" (21).

A key feature of labour in high-monopsony-power GVC segments, such as in garments, is that workers are at the low-wage end. They do not have the luxury of not working, being unemployed. If the low wage they are offered results in them mining their own bodies - that is, not consuming as many calories as they expend in production, they cannot really leave the employment as the alternative in the unorganized sector would be less than half of what they can earn, including overtime, in the garment factory.

Some features of labour conditions in global monopsony capitalism with the greatest power of brands, as in garments and agro-foods, are: low wages, precarious employment and forced labour. In particular, when we look at monopsony capitalism from the viewpoint of the Global South, these features are not something new. Wages have been low and employment has been both precarious and informal. Forced (including bonded) labour is not something new, with the Indian caste system being an exemplar of both forced and bonded labours. The point is that these features of poor employment quality have been brought into monopsony capitalism, both domestic and global.

There is also an intersectionality of various forms of oppression, or their conjugated oppression (Bourgois 1988). This makes labour non-homogenous, allowing the monopsonist to adopt different wage levels for different segments of labour, a phenomenon Joan Robinson called discriminating monopsony (1987/1969, 227). This can take the form of marginalized migrants being paid less than local workers in the lower ends of the value chain, or, in India, the addition of forms of marginalization and oppression of the Dalits, the former untouchable castes, in addition to women getting less (AFWA 2021).

One feature of work in the garment manufacture is that of high levels of overtime. Apart from being forced to accept overtime because of low wage levels, there is also punishment for refusing overtime. This is combined with the intensification of work with reduced lead times in this time of fast fashion. Forcing workers to attain production schedules is often carried out through abusive and gender-based violence, treating workers as captives with no human rights. The result of overwork is a mining of women's garment workers' bodies, resulting in them being expelled from factory work when they are around 35 years old (Nathan et al. 2022a).

Work in these low-knowledge segments is often outsourced from supplier factories to both "shadow factories" and home-based workers, with even worse conditions of employment than in the factories. There is a high proportion of women in these segments, with women overwhelmingly dominating the homeworker segment. Agricultural production in GVCs, such as cocoa (Barrientos 2014) and fresh vegetables and fruits (Evers et al. 2014), is often carried out on small farms, subsuming within them the labour of women and men as self-employed workers for GVCs (Barrientos 2019). 
Child labour exists in global value chains such as garments, carpets and handicrafts, in locations that are difficult to monitor, such as the household. However, they have formed an integral part of value chain production (Phillips et al. 2014; Nathan et al. 2018b). Forms of modern slavery exist in global value chains for minerals (Nathan and Sarkar 2011), manufacturing such as ship-breaking (IndustriAll 2015), fisheries (ILO 2017), cocoa (Barrientos 2019) and many other primary commodities that are raw materials.

Forced overtime and the general pattern of supervision by verbal abuse-sexual abuse in the case of women workers-with the addition of casteist abuse in India lead to the somewhat startling conclusion that all workers in garment supply factories are the victims of forms of forced labour. These are aspects of work in the sweatshop regime (Mezzadri 2016) with high monopsony power of the band/lead firms.

\section{Platforms: High Monopsony Power}

Platforms have used their monopsony power to initially attract workers by offering higher returns and then reducing these as the number of workers grows. This surplus workforce weakens the workers and strengthens the platforms on which they depend to get work. This allows the platforms the power to increase their own share of earnings, literally increasing their own commissions at will, though within limits. When the then-CEO of Uber was asked why commissions were being increased from 25 to 30 per cent, his reply was, "Because we can," (quoted in Woodcock and Graham, 2020). This simple statement is indicative of the enormous monopsony market power of platforms vis-à-vis their workers. Since gig workers must invest to purchase the means of production, they are tied-in to the industry, if not to a particular firm. But given the advantages of scale, the number of options in any service is quite limited, such as Uber and Lyft only for taxi services in the USA, or Uber and Ola in India. The locational platforms which provide area-based services should be classified as having high monopsony power.

Regarding earnings from locational platforms, the ILO concludes that hourly earnings for app-based taxi drivers and delivery workers tended to be higher than in the traditional sectors (ILO 2021, 6). However, they worked for longer hours and with greater intensity. Work averaged $65 \mathrm{~h}$ per week in the taxi platforms and $59 \mathrm{~h}$ per week in delivery platforms.

Wages per hour calculated for digital work on online platforms tended to be far below the hourly minimum wages in the USA, while they provided reasonable incomes in lower-middle-income India (D'Cruz and Noronha 2016). There is an interesting dynamic in this cross-country income system in online web-based work. In the crowdsourcing system, workers from high-income countries compete with those with similar capabilities from low-middle-income countries. There is a single price for a task, whether it is performed by a worker in the USA or a worker in India. Is this the beginning of a truly global labour force as argued by Graham and Anwar (2019)? This could happen in online web-based work, rather than in areabased locational work. In the latter, a taxi ride in New York would still cost more 
than a taxi ride in Delhi. However, in online web-based work there may be no difference in payment based on location, while skill and reputation are what would matter.

\section{Medium Monopsony Power}

Medium monopsony power GVCs, such as electronics assembly or automobile manufacture, require knowledge that is of moderate complexity, but high codifiability. These GVC segments also require workers with a reasonable level of education-at least a high school degree. Orders, however, are volatile, particularly in electronics, and this leads to substantial employment of temporary and agency workers (for electronics in Thailand, see Holdcroft 2012), estimated by Verite to be about $25 \%$ of the electronics workforce in Malaysia (Raj-Reichert, 2020), and, correspondingly, low employment security in some countries and high levels of overtime in others (for China, see Chan, Pun and Selden 2016, for Malaysia, see Samel 2012).

All value chains extend beyond factories. Raw materials for electronic products are procured from the mining of minerals, such as coltan from the Democratic Republic of Congo, where the worst abuses of forced labour under armed gangs have existed (Nathan and Sarkar 2011). Within the core factories, however, we should contrast the virtual $100 \%$ of forced labour in garment factories with the $25 \%$ in electronics factories as one indicator of the difference between high and medium monopsony power.

\section{Low Monopsony Power}

In low-monopsony-power GVCs, such as in IT software services, the knowledge requirements are more complex, involving some design aspects apart from the development and maintenance of IT systems. Monopsony power is low because the suppliers and workers can easily shift between different value chains. However, even in this, there is a division of labour, with design often being undertaken in headquarter economies and the development and maintenance of systems undertaken in developing countries. Indian IT firms, for instance, were concentrated in the middleto lower-complexity sections (Sarkar et al. 2013), though they have been moving into design and full-package supply (Ahmed 2018).

In IT software GVC segments, workers are required to have a high level of knowledge and employment is comparatively secure. However, the drive to reduce costs makes employees vulnerable to "bell curve" methods of dismissal, where a certain percentage of employees who are at the bottom of the curve are dismissed each year. Earnings, however, are consistently higher than for employees of comparable qualifications in other sectors (Sarkar and Mehta 2016). This is possible due to relatively high margins-from 17 to $25 \%$-in the IT software services industry.

In concluding this section, in production segments requiring low levels of knowledge and subject to captive governance by brand-lead firms there is high monopsony power, which is reflected in high levels (virtually 100\%) of forced labour in labourintensive production systems. In the production segments requiring somewhat higher 
levels of knowledge with modular governance, such as electronics or automobile manufacture, there is a medium level of monopsony power, reflected in the medium levels (about 25\%) of forced labour. In the high knowledge segment of IT services, the brand-lead firms have low levels of monopsony power, while IT workers, with their ability to switch sectors, also would not exhibit forms of forced labour, though there are monopsonist practices such as "no compete" and "no poaching" agreements in play.

Before concluding this paper, the next section tries to see how monopsony power works though or intersects with gender. A gender wage gap through unequal pay for equal work would be a clear case of the employers' power in setting wages.

\section{Gendered Working of Monopsony Power}

The gender wage or pay gap within firms shows that monopsony works in different ways between genders. Robinson did relate her analysis of monopsony to the gender wage gap and found the likely reason for the gap in men being more unionized than women, with unionization expected to result in higher wages (1987, 302-4). Manning argues that the gender pay gap is better explained by monopsony rather than the often-used human capital theory. Human capital is supposed to work through productivity, with women's supposed lower productivity being the reason for lower wages. Manning argues that the absence of an adverse effect on job opportunities, subsequent to the implementation of the UK Equal Pay Act, is evidence in favour of the monopsony explanation, since the human capital approach would have predicted a reduction in women's job opportunities because of the UK Equal Pay Act.

Many countries have equal pay legislation, which should prevent unequal pay between genders. Employers get around this by differently classifying women and men workers. In the garment and shoe manufacturing segments in India, employers categorize women at a lower level of semi-skilled workers, while male tailors are categorized as skilled workers.

The high prevalence of gender-based violence also works to enable employers to pay less to women workers. Women mentioned that they tend to leave a garment factory where they have faced explicit calls for sexual favours from supervisory and managerial staff (Nathan et al. 2022a). When they join another garment factory, they lose whatever seniority they would have earned, thus preventing them from climbing up the job ladder. This switching of jobs for non-economic reasons would result in a gender wage gap, as pointed out in Manning (2003).

The gendered working of monopsony power is clearly seen in the forced retirement of women from garment factories at a very young age. There are hardly any women above the age of 35 in garment factories in India, Bangladesh or Cambodia (Nathan et al. 2022a). Material from Latin America also points to this early age of retirement of women from factory work and the recruitment of a younger age cohort. Manning points out that one indicator of monopsony power can be the incidence of recruitment from non-employment $(2003,195)$. With women being routinely pushed out by the age of 35 , and young first-time workers being brought in, this shows a high level of monopsony power in the garment value chains. 
What this discussion points to is that there is scope for exploring monopsony as an explanation of the gender wage gap and other gender differences in employment. Monopsonist firms clearly decide to pay lower wages to women, utilizing the vulnerabilities of women in employment. One aspect of these vulnerabilities is the extraction of unpaid care work from women.

Monopsony is gendered. Similarly, monopsonist firms would be expected to use the power of setting wages in the intersection of employment policy with social identities, such as caste, ethnicity and race. There is a lot of analysis of the segmentation of the labour market, mainly based on characteristics of workers, such as gendered responsibilities for unpaid care work and so on. What the introduction of monopsony into this analysis would do is to bring the employers' power to set wages and other conditions of work into the analysis of these segmentations or intersections.

\section{Conclusions: Surplus Extraction and Development}

Monopoly capitalism in headquarter economies of the Global North has become global monopsony capitalism. The subsequent development of platform-based firms has pushed outsourcing to a new level. The platforms own nothing but the consumer interface or access to markets; inventories are outsourced to brands and service provision to millions of crowdsourced workers, who bring with them the requisite means of production. This is the world of monopsony capitalism.

Before concluding, there are a couple of points to note about placing monopsony capitalism in the context of trajectories in the global economy, emphasizing that these structures are not impermeable but subject to evolutionary development. The first point is about workers in monopsony capitalism: their conditions of employment, even in production segments with high monopsony power, may yet be better than what they could get elsewhere in their economy in the Global South. This was pointed out with regard to garment workers in Bangladesh that their wages were higher than in available alternate work in the informal sector (Kabeer, 2002). This was also pointed out with regard to gig workers in online web-based platforms in India (D'Cruz and Noronha 2016). We should expect this comparison to hold across other GVC segments and economies across the Global South. This does not mean that we should stop pointing out the existence of forced labour and other violations of decent work conditions. Both points need to made that the forms of GVCs, including gig work, are often better than other informal sector alternatives, but also that they seriously violate preferred conditions of decent work.

The second point is that surplus extraction from economies of the Global South does not mean that there is no scope for local accumulation and development in these economies. The very reversal of the Great Divergence between Europe and Asia shows that such accumulation and development are possible. This would not happen just by following market-fundamentalist principles of economic policy, but by adopting deliberate capability-building, including in women and men, and industrial and knowledge development policies. This is a very large topic, some of which is dealt with in Nathan (2018a). It is mentioned 
here to show disagreement with those analyses that consider monopoly-monopsony forms of surplus extraction as precluding any trajectory of development in economies of the Global South. The very fact that countries have gone beyond catch-up (Nayyar 2019) means it is necessary to explain how this might occur even in a monopoly-monopsony global economy. Even durable inequalities (Tilly 2005) are not cast in stone, they are permeable, provided appropriate industrial and knowledge policies are followed.

In conclusion, we consider some policies that could be adopted to deal with global monopsony power. Inelasticity of labour supply creates the vulnerability of workers to monopsony power. With the strong tendency to push down wages, there clearly is a role for minimum wage interventions to raise the floor of the wage level in each regional income region-raising minimum wage levels for high-income, upper-middle income, lower-middle income and low-income economies. This would be needed to deal with the race-to-the-bottom dynamic that global monopsony capitalism sets in place. This raising the level of minimum wage needs to be combined with some forms of affirmative action to counter the greater vulnerability of women, minorities, Dalits in India, and other marginalized social groups subject to forms of conjugated oppression. For small holders such as farmers or gig workers, some form of collectivization, whether as unions or some other form of organization, could play a role in controlling supply and raising producer incomes.

Building countervailing forces to the power of global monopsonies is the monumental task for those who would improve the working conditions of workers, women and men, in both the Global South and the Global North. The globalization of monopsonies makes the task of building countervailing power a global task, and one requiring the bringing together of various types of movements, not just of affected workers, but also of women, environmental movements, ethical consumer and share-holder movements. This truly is a monumental task made necessary in the age of monopsony capitalism.

Acknowledgements I was very fortunate to receive comments from Raphie Kaplinsky, Will Milberg, Gerry Rodgers and Ashok Kumar. There was no funding support for writing this paper, except from my wife, Govind, who not only supported this unpaid labour, but also provided continuous discussion and advice during early morning coffee over many months. Thanks to Somnath Basu for proofreading. The usual caveat about responsibility for errors applies.

Authors' contribution There is just a single author.

Funding No funding was received for writing this paper.

\section{Declarations}

Conflict of interest There is no conflict of interest with other work done by the author.

Ethics Approval Not Applicable.

Consent for publication I agree to the publication of this paper in the Indian Journal of Labour Economics. 


\section{References}

Apparel Export Promotion Corporation (AEPC). (2020). Impact of COVID on apparel exports. Www. aepc.org. Accessed 1 Jun 2020.

Ahmed, Neetu. 2018. Strategic change in Indian IT majors: A challenge. In Development with global value Chains: Upgrading and innovation in Asia, ed. Dev Nathan, Meenu Tewari, and Sandip Sarkar, 229-246. Cambridge: Cambridge University Press.

Asia Floor Wage Alliance. (2021). Money heist: Covid-19 wage theft in global garment supply chains.

Anner, Mark, Jennifer Bair, and Jeremy Blaisi. 2014. Towards joint liability in global value Chains: Addressing the root causes of labor violations in global production. Comparative Labor Law Policy 35 (1): $1-43$.

Anner, Mark. 2020. Leveraging desperation: Brand practices during the pandemic. Center for workers' rights. Pennsylvania State University. https://www.workersrights.org/wp-content/uploads/2020/10/ Leveraging-Desperation.pdf. Accessed 7 Sep 2021.

Ashenfelter, Orley, Henry Farber, and Michael Ransom. 2010. Labor market monopoly. Journal of Labor Economics. 28 (1): 203-210.

Azar, Jose, Iona Marinescu, Marshall Steinbaum. (2019). Labor market concentration. Accessed 22 Jul 2021.

Baldwin, Richard. 2016. The great convergence. Cambridge, MA: Harvard University Press.

Baran, Paul, and Paul Sweezy. 1966. Monopoly capital: An essay on the American economic and social order. New York: Monthly Review Press.

Barrientos, Stephanie. 2014. Gendered production networks: Analysis of cocoa-chocolate sourcing. Regional Studies 48 (5): 791-903.

Barrientos, Stephanie. 2019. Gender and work in global value chains: Capturing the gains? Cambridge: Cambridge University Press.

Bourgois, Philippe. 1988. Conjugated oppression: Class and ethnicity among Guyami and Kuna Banana workers. American Ethnologist 15 (2): 328-348.

Brooks, Wyatt, Joseph Kaboski, Yao Amber Li and Wei Qian. (2019). Exploitation of labor? Classical monopsony power and labor's share. Working Paper 25660. Cambridge, MA: NBER.

Chan, Jenny, Pun Ngai, and Mark Selden. 2016. The politics of global production: Apple, Foxconn and China's new working class. In Labour in global value chains in Asia, ed. Dev Nathan, Meenu Tewari, and Sandip Sarkar, 353-376. Cambridge: Cambridge University Press.

Colvin, Alexander and Heidi Shierholz. (2019). Noncompete agreements: Ubiquitous, harmful to wages and to competition, and part of a growing trend of employers requiring workers to sign away their rights. Washington, DC: Economic Policy Institute. https://files.epi.org/pdf/179414.pdf. Accessed 22 Jul 2021.

D'Cruz, Premilla, and Ernesto Noronha. 2016. Positives outweighing negatives: the experiences of Indian crowdsourced workers. Work Organisation, Labour and Globalisation 10 (1): 44-63.

Durand, Cedric, and William Milberg. 2019. Intellectual monopoly in global value Chains. Review of International Political Economy. https://doi.org/10.1080/09692290.2019.1660703.

Emmanuel, Arghiri. 1972. Unequal exchange: A study of the imperialism of trade. New York: Monthly Review Press.

Evers, Barbara, Flavia Amoding, and Aarti Krishnan. (2014). Social and economic upgrading in floriculture global value chains: flowers and cuttings GVCs in Uganda. Capturing the Gains, Working Paper 2014/42. Available at http://www.capturingthegains.org/publications/workingpapers/wp_ 201442.htm. Accessed Dec 162020.

Exchange Media Staff. (2019). Times group signs non-poaching agreements with HT and Telegraph. https://www.exchange4media.com/media-print-news/times-group-signs-non-poaching-agreementswith-ht-and-telegraph-16366.html. Accessed 6 Sep 2021.

Freeman, Richard. (2005). What really Ails Europe (and America): The doubling of the global workforce. In The Globalist. June 3.

Gereffi, Gary, John Humphrey and Timothy Sturgeon. 2018 (2005). The governance of global value chains. In Gary Gereffi, Global value chains and development: Capitalism in the twenty-first Century. Cambridge: Cambridge University Press. pp. 108-136

Ghosh, Anwesha, Risha Ramachandran, and Mubashira Zaidi. (2021). Women workers in the gig economy in India: An exploratory study. New Delhi: Institute of Social Studies Trust.

Glyn, Andrew. 2002. Capitalism unleashed. Oxford: Oxford University Press. 
Glyn, Andrew. 2006. Marx's reserve army of labour going global. The Hindu. April 6.

Goodwin, T. (2015). The battle is for the customer interface. Tech-crunch. March 3, 2015. https://techc runch.com/2015/03/03/in-the-age-of-disintermediation-the-battle-is-all-for-the-customer-interface/. Accessed 2 Sep 2021.

Grabs, Janina, and Stefano Ponte. 2019. The evolution of power in the global coffee value chain and production network. Journal of Economic Geography. 19: 803-828.

Graham, M., and Anwar, M. A. (2019). The global gig economy: Towards a planetary labour market? First Monday. 24(4). https://www.oii.ox.ac.uk/blog/new-article-the-global-gig-economy-towards-aplanetary-labour-market/. Accessed 31 Aug 2021.

Hamel, G., and C.K. Prahalad. 1990. The core competence of the corporation. Harvard Business Review 68 (3): 79-91.

Helper, Susan. (1991). Strategy and Irreversibility of the US auto industry. Business History Review. Winter. 781-824.

Holdcroft, J. 2012. The triangular trap: Unions take action against agency labour. Geneva: IndustriAll.

White House. (2021). FACT SHEET: Executive order on promoting competition in the American economy. https://www.whitehouse.gov/briefing-room/statements-releases/2021/07/09/fact-sheet-execu tive-order-on-promoting-competition-in-the-american-economy/. Accessed 21 Jul 2021.

Howe, J. (2006). The rise of crowdsourcing. Wired. 1 May 2006. https://www.wired.com/2006/06/ crowds/. Accessed 31 Aug 2021.

ILO. 2021. World employment and social outlook: The role of digital labour platforms in transforming the world of work. Geneva: ILO.

ILO. (2017). Forced labour and human trafficking in fisheries. Geneva: ILO. https://www.ilo.org/global/ topics/forced-labour/policy-areas/fisheries/lang--en/index.htm. Accessed 19 Jul 2021.

IndustriAll. (2015). Cleaning up ship-breaking: The World's most dangerous job. http://www.industriallunion.org/cleaning-up-ship-breaking-the-worlds-most-dangerous-job. Accessed 19 Jul 2021.

Kabeer, Naila. 2002. The power to choose: Bangladeshi women and labour market decisions in London and Dhaka. London: Verso.

Kaplinsky, Raphael. 2019. Rents and inequality in global value chains. In Handbook of global value chains, ed. Gary Gereffi, Stephano Ponte, and Gale Raj-Reichert, 153-168. London: Edward Elgar.

Konczal, Mike. (2014). The Silicon valley labor scandals prove minimum wage hikes don't cost jobs. New republic. February 14, 2014. https://newrepublic.com/article/116608/silicon-valley-laborscandals-prove-minimum-wage-hikes-dont-cost-jobs. Accessed $24 \mathrm{Jul} 2021$.

Kumar, Ashok. 2020. Monopsony capitalism: Power and production in the twilight of the sweatshop age. Cambridge: Cambridge University Press.

Lenin, V.I. 1966. Imperialism, the highest stage of capitalism. Moscow: Foreign Languages Publishing House.

Manning, Alan. 2003. Monopsony in motion: Imperfect competition in labor markets. Princeton: Princeton University Press.

Manning, Alan. (2020). Monopsony: A review. ILR Review. https://doi.org/10.1177/0019793920922499

Mezzadri, Alessandra. 2016. The sweatshop regime: Labouring bodies, exploitation and garments made in India. Cambridge: Cambridge University Press.

Nathan, Dev. 2018. Imperialism in the twentyfirst century: Global value chains and labour arbitrage. Economic and Political Weekly. 53 (32): 33-39.

Nathan, Dev, and Sandip Sarkar. 2011. Blood on your mobile? Economic and Political Weekly 45 (43): 22-24.

Nathan, Dev, Meenu Tewari, and Sandip Sarkar, eds. 2016. Labour in global value chains in Asia. Cambridge: Cambridge University Press.

Nathan, Dev. 2018a. GVCs and development policy, in Dev Nathan, Meenu Tewari and Sandip Sarkar, eds., Development with global value chains: Upgrading and innovation in Asia. Cambridge: Cambridge University Press, pp 373-408.

Nathan, Dev, Varsha Joshi, Govind Kelkar, Lakshmi Bhatia. 2018b. Business strategies for a child labour free Jaipur. London: The freedom fund. https://freedomfund.org/blog/launch-business-strategiesfor-a-child-labour-free-jaipur/. Accessed 14 Oct 2021.

Nathan, Dev, Shikha Silliman Bhattacharjee, S. Rahul, Purushottam Kumar, Immanuel Dehaghani, Sukhpal Singh and Padmini Swaminathan. (2022a) (forthcoming). Reverse subsidies in global monopsony capitalism: Labour, gender and environmental subsidies in garment value chains. Cambridge: Cambridge University Press. 
Nathan, Dev, Govind Kelkar and Balwant Singh Mehta. (2022b). Platform economy, techno-nationalism and gig workers in India. In Immanuel Ness, Editor. Routledge handbook of the gig economy (forthcoming).

Nathan, Dev. (2020). Knowledge, oligopoly and labour in GVCs. Global Labor Journal. 11, 2. https:// doi.org/10.15173/glj.v11i2.3815

Nayyar, Deepak. 2019. Resurgent Asia: Diversity in development. Oxford: Oxford University Press.

OECD. (2020). Global value chains and trade. https://www.oecd.org/trade/topics/global-value-chainsand-trade/. Accessed 6 Sep 2021.

Oxfam. (2018). Ripe for change: Ending human suffering in supermarket supply chains. https://policypractice.oxfam.org/resources/ripe-for-change-ending-human-suffering-in-supermarket-supplychains-620418/. Accessed 14 Jul 2021.

Pagano, Ugo. 2014. The crisis of intellectual monopoly capitalism. Cambridge Journal of Economics 38: 1409-1429.

Phillips, Nicola, Resmi Bhaskaran, C. Upendranadh and Dev Nathan. (2014). Social foundations of global production: Unfree labour,' in Third World Quarterly. 428-446. https://doi.org/10.1080/ 01436597.2014 .893486

Pistor, Katharina. 2021. Biden's pro-competition agenda could fix America's free market. Mint. July 21, 2021.

Raj-Reichert, Gale. 2018. The changing landscape of contract manufacturers in the electronics industry in Asia. In Development with global value chains: Upgrading and innovation in Asia, ed. Dev Nathan, Meenu Tewari, and Sandip Sarkar, 20-62. Cambridge: Cambridge University Press.

Raj-Reichert, Gale. 2020. The powers of a social auditor in a global production network: The case of Verite and the exposure of forced labour in the electronics industry. Journal of Economic Geography. 20: 653-678.

Rikap, Cecilia. 2021. Capitalism, power and innovation: intellectual monopoly capitalism uncovered. London: Routledge.

Robinson, Joan. (1987). The economics of imperfect competition. London: Macmillan.

Samel, Hiram. 2012. Upgrading under volatility in a global economy. MIT Sloan School of Management. Avialable at http://ssrn.com/abstract+2102643. Accessed 9 Dec 2014

Sarkar, Sandip, and Balwant Singh Mehta. 2016. What Do workers gain from being in a GVC? ICT in India. In Labour in global value Chains in Asia, ed. Dev Nathan, Meenu Tewari, and Sandip Sarkar, 450-478. Cambridge: Cambridge University Press.

Sasi, Anil. (2018). Views on how a few firms' dominance affects market structure. The Indian Express, September 3. Accessed 24 Jul 2021.

SEWA. (2021). Informal workers in the pandemic. Ahmedabad: SEWA (mimeo)

Smith, John. 2016. Imperialism in the twentyfirst century: Globalization, super-exploitation and capitalism's final crisis. New York: Monthly Review Press.

Suwandi, Intan. 2019. Labour-value commodity Chains: The hidden above of global production. Analytical Monthly Review 17 (4-5): 46-67.

Thornton, Robert. (2004). Retrospectives: How Joan Robinson and B.L. Hallward Named Monopsony. Journal of Economic Perspectives. 18,2: 257-261.

Tilly, Charles. 2005. Identities, boundaries and social ties. London: Routledge.

Vaughan-Whitehead, Daniel and Luis Pinero Caro. (2017). Purchasing practices and working conditions in global supply chains: Global Survey results. INWORK Issues Brief No. 19. Geneva: ILO

Woodcock, Jamie, and Mark Graham. 2020. The gig economy: A critical introduction. Cambridge: Polity Press.

Publisher's Note Springer Nature remains neutral with regard to jurisdictional claims in published maps and institutional affiliations. 